\title{
The Examination of Listening Anxiety Level of the Students Who Learn Turkish as a Foreign Language ${ }^{i}$
}

\author{
Sercan Halat ${ }^{1, *}$, Murat Özbay ${ }^{2}$ \\ ${ }^{1}$ Turkish Language Arts, Muğla Sttkı Koçman University, Turkey \\ ${ }^{2}$ Turkish Language Arts, Turkey
}

Copyright $\bigcirc 2018$ by authors, all rights reserved. Authors agree that this article remains permanently open access under the terms of the Creative Commons Attribution License 4.0 International License

\begin{abstract}
In 21st century which witnesses a range of extraordinary technological improvements; along with the world's turning into global-village-like place, it is a vital need that a common communication network being built up as a result of the interaction among the people whose nation, culture, language and beliefs differ drastically. With the aim of meeting this need, developed and developing countries have started to perform various studies in order to spread their languages all around the world. Similarly, one of those countries is Turkey where many studies are conducted in favour of teaching Turkish as a foreign language systematically and effectively. It is obvious that most of the studies are generally centered upon 'learning environment', 'curriculum' or 'learning materials'. However, cognitive-psychological dimension of learning is ignored. During the process of speaking, reading or writing in the foreign language, learners frequently develop anxiety and desperation. With the high level of anxiety, success in language education decreases considerably. This is the case for the listening skill which has an important place in language development. Since learners need to understand messages clearly and thoroughly in order to response properly, anxiety during listening or communication disorders resulting from it will affect development of language skills, making it impossible for people to communicate healthily.
\end{abstract}

Keywords Teaching Turkish as a Foreign Language, Listening Skill, Anxiety

\section{Introduction}

Through the ages, people have always communicated through language, stated what they want and built and established new civilizations by commencing in economic activities. There have been a number of different definitions of language that is the milestone of these civilizations and an indispensible part of our lives.
According to Ferdinant de Saussure [1], despite being the most important part, language constitutes only a specific part of linguistic competence. Linguistic competence is a reflection of human's inherent ability to communicate while language is an acquired characteristic that comes from understanding each other. As he describes language, Saussure differentiates langue (French, meaning "language") and parole (meaning "speaking"). When the linguistic system is used as a tool for communication, consists of rules and codes that all participants must act accordingly. Rules are principles that are learned while learning a language and it allows you to express everything that you want to say correctly. For example, while the word order in English is subject-verb-object, in Turkish the verb usually goes at the end of the sentence. Saussure refers to this structure that is bound by rules as language. On the other hand, word is a notion that defines language. Saussure associates communication between individuals that are connected to each other by linguistic competence. Saussure refers communication, that individuals connected by linguistic competence conduct by using nearly identical notions and indicators, as "crystallization". He states that the act of actualization cannot be performed as a community and it is always individualistic and identifies this personal sovereignty as verbalism [2].

According to Chomsky, language consists of an infinite number of words. Each of these words has an infinite length and infinite parts of speech. Linguistic competence is exclusive to humans and all humans have different levels of linguistic competence. Through linguistic competence, complex languages can be created with simple input [3]. As a matter of fact, this opinion explains the existence and variety of languages scientifically. The people who live in societies which speak these languages that have a distinctive pattern and systematic are naturally expected to interact personally or legally with people from other societies for social, political or economic reasons. As a result of societies getting closer to each other with the development of technology in the last century, the need for learning a foreign language emerged and therefore the 
concept of foreign language teaching has started being handled by scientists.

There can be several reasons why an individual wants to learn a foreign language. Reasons such as curiosity, education, business, personal interest can motivate a person to learn a foreign language. The most common reasons to learn a foreign language is education and business. From this perspective, the position of English is remarkable. English has turned into a world language from being the language of a small society. It has reached this position by the economic, military and cultural success of the countries which speak English. British people have been aiming to spread their language and culture to the world with the help of British Council. This aim has created an opportunity for English to become a worldwide communication language. With the increasing worth and number of students that are being taught Turkish as a foreign language, some problems have occurred during the process of teaching language skills to individuals who learn Turkish. When language teaching and psychological aspects are mentioned, the first thing that comes to mind is anxiety. Anxiety has been the most common psychological condition humanity had to face throughout history. This notion has first been introduced in the first half of the century and studies that concern this area have started being conducted by the end of 1940's [4].

The person who used the word "anxiety" for the first time in the field of psychology is Freud and he was also the one who defined it as a notion while searching for its reasons. According to Freud, anxiety contributes the individual's ability to survive, warns the individual against the physical or social threats or helps them adapt. On the other hand, according to Beck and Emery, anxiety reflects a state that causes the individual discomfort when the fear takes over. Anxiety, which we can summarize as a reaction of the human body in face of a danger, emerges especially during the process of learning a language [5]. While listening, speaking, reading or writing in a foreign language, individuals may experience anxiety and often they don't know what to do about it.

The state of anxiety makes its presence felt during listening which is the first skill to be acquired among the fundamental language skills and also has a very important place. As the individuals need to understand the message correctly and clearly during communication in order to give a response, the individual goes through anxiety or miscommunication during listening. This will affect the progress of other language skills and make it impossible to have a healthy communication system among individuals.

\section{Anxiety of Foreign Language and Listening}

Anxiety is generally defined as a state of discomfort, concern or a feeling of fear that an individual go through in the face of a threatening situation [6]. In other words, it it is a feeling that fears something without knowing what the problem is [7]. Spielberg [8] defined anxiety as observable reactions such as sadness, perception and distress that are caused by stressful situations. According to the definition of American Psychology Association [9] anxiety is a distress signal which emerges on the conscious part of the brain. This threat is produced within the personality or in the external environment dependably or independently. Moreover, in Turkish dictionary anxiety is defined as "sadness, a thought that causes concern" [10]. As it is understood from all these definitions, anxiety is the integration of people's fears with the images that form in their brains. Anxiety which is one of human's basic emotions and sensations is often experienced and affects human life [11].

Anxiety is a reaction to problems. When things go wrong or in the face of a bad situation or when individuals fail to get results that they want, they start to get anxious. Aside from this, some personality traits cause the anxiety levels to rise during learning a foreign language. For example, when perfectionist people face with any kind of failure, they immediately fall in despair and the way they criticize themselves may affect the learning process negatively [12]. Despite all the negative aspects, anxiety also has different features such as stimulating, protecting or motivating the organism. The ability to brace oneself against injuries, pain, punishment, separation or disappointment can be shown as an example of anxiety's simulative feature; or the fact that a person takes precautions in order to get over any other problems easier is an example of protective feature of anxiety and how the concern of failure drives a person to work harder can be an example to the motivating feature of anxiety [13].

On the other hand, foreign language anxiety is a kind of anxiety that stems from the uniqueness of the process of learning a foreign language, a sense of self that is special to foreign language classes and a combination of emotion and behaviors [14]. Hortwiz and Cope [14] drew attention to the different aspects of this special kind of anxiety among the other types of anxieties and stated that foreign language anxiety should be handled separately. According to Guiora [15] as foreign language learning can directly threaten an individual's world view and the concept of personal self, it's a very discomforting psychological theorem. If the foreign language learning turns into a discomforting psychological problem, we can assume that there can be an imposition and thus, the possibility that the individual's sense of self which desires to be free can feel discomfort because of an imposition. In these cases the discomfort that the individuals feel is very natural. However, foreign language anxiety is discontinuous. It emerges temporarily and shows itself on only specific situations. Therefore, individuals who experience this kind of anxiety, does not have a tendency to be constantly worried. Consequently, these kinds of individuals only experience momentary anxiety in certain situations such as the fear of speaking in front of a crowd.

Scovel [16] claims that we need to separate the kind of anxiety that prevents the students' success (debilitating anxiety) and the kind of anxiety that makes it possible for 
an individual to achieve beyond their capabilities (facilitating anxiety) from each other. While positive anxiety triggers student's desire to learn and encourages the student to actively participate in the process of learning, negative anxiety causes the student to feel extreme sadness, and cause them to doubt themselves, which results in using the target language less and less [12]. Anxiety, can surface alongside resisting the process of foreign language learning, feeling unsafe and uneasiness. While it doesn't have much importance in the beginning of the learning process when the individuals have high motivation, as the time progresses, anxiety increases as a result of repetitive problems [17].

According to Littlewood [18], the classroom environment which he sees as unfit to learn a foreign language naturally, also causes students to feel weak. In a classroom environment, if they can't express themselves with a proper pronunciation in the target language that they have just started to learn, they think that they are going to be criticized or corrected by their teachers or they think that they are going to be mocked by their peers. The individuals who feel themselves in an unsafe and disconcerting environment psychologically shut themselves to communication in a foreign language. If this situation progresses any further, it may cause the learning process to slow down or even completely stop. At this point, teacher's attitude and behaviors in the classroom directly affects the educational environment and therefore the students' manners, behaviors and levels of distress.

According to Gardner and MacIntyre [19] foreign language anxiety is defined as a feeling of tension and concern that is directly related to education of foreign and second languages which includes learning, listening and speaking.

According to Young [20] foreign language anxiety is a type of anxiety that caused by:

- personal and interpersonal differences,

- individual differences concerning language learning,

- tutor beliefs concerning language learning,

- teacher-student interactions,

- classroom environment and language tests.

Foreign language anxiety, can surface in many different ways as everyone has different experiences, ideas and emotions towards foreign language learning. The language courses that the individuals participated in during their education might also cause them to have a negative attitude. As a result of this negative attitude, it's often very hard for individuals to cope with the anxiety they experience.

As we can see, in the process of teaching basic language skills, there are lots of different factors that trigger individuals' foreign language anxiety. This high level of anxiety also depends on the level of language skills. Studies have shown that the anxiety that occurs during speaking and listening activities is higher compared to reading and writing skills. To be more specific, the most problematic skill for the students to improve is listening.
The reason of this is the fact that listening skill includes a wide variety of complex functions; such as communication, understanding, and being understood, acquisition of knowledge, learning and problem solving which requires certain abilities. However, research studies on education reveal that the most needed and used skill in a classroom environment is listening [21]. This situation shows that when it comes to academic achievements, rather than attitude or reading skills, listening is more effective [22]. In order to get any benefit from the listening tasks that are done at schools, there are some pre-conditions which need to be taken under consideration such as readiness, attention and the role of the teacher. Özbay [23] states this matter as, "The most important aspects of listening are environment, a proper place and teachers who are trained with the correct materials."

Listening is a communicative skill that is heavily influenced by psychological and social factors. The attribution of listening can change depending on attributes of the message received, visual behaviors of the message source, how the communication tool (voice) is used, what the purpose of the listener is and many other factors [24]. Factors like emotions and excitement is the basis of miscommunication or missing information. These two factors are generally the reason of deficient listening [25].

There are two fundamental purposes of teaching language skills in foreign language learning. First purpose is to allow the student to understand the information given about target language in target language. Second purpose is to ensure the individuals who are learning a foreign language to communicate successfully. The comprehension of the meaning relations is a very important matter on understanding the messages exactly and correctly. A successful listening is thought to be very important regarding communication, which is the corner stone of foreign language teaching [26].

The first time listening skills have been classified as a subject matter on education dates back to 1900's in the Western world. As a result of the researches, listening has been seen as one of the most fundamental language skills and found itself a place on the curriculum. On the other hand, we see that these researches only have been conducted in Turkey towards the end of the $20^{\text {th }}$ century. Doğan states that the reason why listening is neglected and why we remained insensitive to this skill is caused by different factors. Most teachers believe that listening is acquired naturally and there is no need to lean on this subject in order to teach listening. Some teachers on the other hand, believe that listening cannot be taught or even if it is taught, it cannot be evaluated. Moreover, some teachers believe that the schedule is already very busy and that there is no time to spare for listening practices [27]. In order to teach such an important skill at a competent level, teachers should be freed of this kind of perception. Otherwise, listening cannot be interiorized and thus, the targeted level of success in language teaching cannot be reached. Having said that, in today's world the importance 
of using listening skill effectively and efficiently in both native and target language comes to light with the head spinning development of technological advancements and how humans are bombarded with messages from all over the world [28]. Furthermore, According to the idea of how fundamental language skills are connected to each other, using the listening skill in a healthy way, which is the first skill that an individual acquires, makes using other skills in an effective and decent way easier.

In the latest years, a major increase is seen on the research about anxiety and foreign language teaching especially in America and Europe. The reason for this is how the idea that language learning is related to the psychological structures gained recognition by scientists in the last half of the century. However, when we think about the connection between the psychological aspects of Turkish and foreign language teaching, the researches that had been conducted on this area is neither sufficient nor efficient. With an education system that does not take an individual's psychological state under consideration, it is nearly impossible to get the wanted results.

In this research, it is aimed to investigate the level and reasons behind the anxiety that the students' who learn Turkish go through during listening practices. In regard to this primary aim, the answers of the questions below were sought:

- What is the level of anxiety that the students who learn Turkish go through regarding the listening skill?

- What are the factors that affect the level of anxiety that the students go through as they learn Turkish as a foreign language regarding the listening skill?

a. Does the level of listening anxiety in Turkish learners change according to gender?

b. Does the level of listening anxiety in Turkish learners change according to age groups?

c. Does the level of listening anxiety in Turkish learners change according to their education level? e. Does the level of listening anxiety in Turkish learners change depending on if they know another language?

- What are the views of individuals who learn Turkish as a foreign language concerning listening anxiety?

\section{Materials and Methods}

This research, which aims to examine the level of anxiety that the Turkish learners go through and the reasons behind it, is meant to be both quantitative and qualitative.

\subsection{Research Design}

Gazi University and Hacettepe University Turkish
Learning Research and Application Centers have tried to determine the listening anxiety of the students who learn Turkish as a foreign language, level of their anxiety and the reasons behind it. When viewed from this aspect, the research is a screening model. According to Büyüköztürk [29] in screening models, regarding a certain subject or situation, the participant's ideas, interests, skills, abilities, attitude and similar aspects are tried to determined.

\subsection{Study Group}

This research's universe, which aims to examine the level of stress that people who learn Turkish as a foreign language go through regarding the listening skill, is made out of students who study Turkish as a foreign language. As it's not possible to reach the entire universe of this research, it is deemed suitable to select a universe to further pursue the research. The universe of research is a group on which the researcher makes direct observations or presents an opinion depending on a selected sample set. In practical terms, the studies are done on the research universe and therefore the results should only be generalized on this area [30]. From this perspective, at Gazi University and Hacettepe University Turkish and Foreign Languages Research and Application Centers (TÖMER) has included B1 and B2 level students - according to Common European Framework of Reference for Language - during 2014-2015 academic years and did not resort to getting samples. From Gazi University TÖMER, 82 male and 59 female students and from Hacettepe University TÖMER, 25 male and 21 female students participated in the research. According to this, 187 people participated in this study $(80$ female and 107 male) in total. You can see the participant's age groups on the table below.

Table 1. Age Groups of the Participants

\begin{tabular}{|c|c|}
\hline Age Groups & N \\
\hline $18-22$ & 95 \\
\hline $23-27$ & 69 \\
\hline $28-32$ & 19 \\
\hline $33-37$ & 4 \\
\hline Total & 187 \\
\hline
\end{tabular}

As we can understand from the first table the majority of the study group consists of participants between the age groups of 18-27. The distribution of the students, who experience anxiety (regarding listening practices) while learning Turkish as a foreign language, according to their level of education, is shown below.

Table 2. Participants' Level of Education

\begin{tabular}{|c|c|}
\hline Level of Education & N \\
\hline High School & 5 \\
\hline Under Graduate & 120 \\
\hline Master of Science & 48 \\
\hline Doctorate & 14 \\
\hline Total & 187 \\
\hline
\end{tabular}

When we look at the level of education of the students 
who learn Turkish as a foreign language; aside from 5 students who finished their high school education but didn't continue any further and 120 students who are still doing their undergraduate studies, there are 48 master's students and 14 doctorate students. What languages do the students who participate in this study know are shown on Table 3 .

Table 3. Foreign Languages of the Participants

\begin{tabular}{|c|c|c|c|}
\hline Language & $\mathrm{N}$ & Language & $\mathrm{N}$ \\
\hline German & 2 & Kazakh & 3 \\
\hline Arabic & 22 & Kurdish & 4 \\
\hline Chinese & 2 & Macedonian & 1 \\
\hline Indonesian & 1 & Portuguese & 1 \\
\hline French & 18 & Rumanian & 1 \\
\hline Indian & 1 & Russian & 11 \\
\hline English & 162 & Tajik & 1 \\
\hline Spanish & 4 & Urdu & 2 \\
\hline Italian & 3 & None & 10 \\
\hline
\end{tabular}

According to table 3 , it can be observed that most of the students know English as a foreign language. In addition to this, Arabic and French are also amongst the most spoken foreign languages.

\subsection{Gathering Data}

In order to reach the target and solve the mentioned problems, three data collection tools were used. These data collection tools are personal information form, Foreign Language Anxiety Scale and semi-structured interview form. There are 11 questions on the personal information form which is prepared by the researcher. While 7 of these questions are open-ended, the other questions' answer categories are pre-determined. 3rd, 4th, 5th and 9th questions and "Foreign Language Anxiety Scale" developed by Kim [37] and adapted to Turkish by Kılıç [38], aims at finding answers to the underlying problems of the research. In addition to this, the rest of the questions are meant to evaluate and get to know the target audience better.

The semi-structured interview form which was developed by the researcher aims to make a more thorough examination of the study group's anxiety levels and it was prepared in a subsidiary nature to Foreign Language Anxiety Scale. There are seven open ended questions on the interview form. During the interviews these questions were asked to the students as their answers were being recorded. The given answers were evaluated by three domain experts.

\subsection{Analysis of the Data}

The data that obtained from personal information form, Foreign Language Anxiety Scale and semi-structured interview form have been subjected to analysis. With the descriptive statistics done on the Scale, the students' level of anxiety have been determined. In order to reveal the relationship between the listening anxiety and gender unpaired sample t-test was used. Moreover, in order to find answers to the remaining underlying problems of the research, unidirectional variance analysis has been used.

For each of the scale items, frequencies and percentages were calculated to make a thorough examination of the students' listening anxiety sources and the level of their anxiety. No changes were made on the semi-structured interview form and the data was interpreted through researcher's analysis. On the statistical analysis, the level of significance was accepted as (p). 05 . When the level of significance is higher than .05 , it has been decided that there is not a significant difference between the groups and the comments were made according to this. Before doing the unpaired sample t-test and unidirectional variance analysis, in order to determine if the data were distributed normally a test of normality was done. As a result of the tests, it has been determined that the data has been distributed normally and that the relevant tests could be done.

\section{Findings}

\subsection{Listening Anxiety in Turkish Learners as a Foreign Language}

What is the level of listening anxiety of the students who learn Turkish as a foreign language?

The total number of listening anxiety in students who learn Turkish as a second language and the result of their standard deviation are shown on the table below:

Table 4. Participants' Listening Anxiety Points

\begin{tabular}{|c|c|c|c|c|c|}
\hline & $\mathrm{N}$ & Min. & Max. & $\mathrm{X}$ & $\mathrm{S}$ \\
\hline 1. Factor & 187 & 29.00 & 90.00 & 58.74 & 13.38 \\
\hline 2. Factor & 187 & 6.00 & 25.00 & 16.88 & 3.78 \\
\hline 3. Factor & 187 & 8.00 & 23.00 & 13.81 & 2.50 \\
\hline General & 187 & 47.00 & 131.00 & 89.44 & 15.89 \\
\hline
\end{tabular}

When we look at table 4 , the average score of the listening anxiety in students who are learning Turkish as a second language according to the first dimension is determined to be ${ }^{\mathrm{X}}=58.754(\mathrm{~S}=13.38)$ and this value might be an indication that the students who participated in the research have medium level anxiety. On the "2nd Factor" dimension the average point of the students is $\mathrm{x}=16.88$ $(\mathrm{S}=3.78)$. This value shows that on the "2nd Factor" dimension, students have a medium level anxiety. On the "3rd Factor" dimension their average point is $\mathrm{x}=13.81$ $(\mathrm{S}=2.50)$ and it can be seen that on this dimension students also have a medium level anxiety level. When we look at the general picture of the scale, the average point is $\mathrm{X}_{=}=89.44(\mathrm{~S}=15.89)$. In total, it is possible to say that the 
participants have a medium level anxiety according to this value.

\subsection{The Factors Which Affect the Listening Anxiety in Students Who Learn Turkish as a Second Language}

\subsubsection{Gender and Anxiety Relation}

Does the listening anxiety in people who learn Turkish as a foreign language differ according to gender?

On this research, in order to find out whether there is a relationship between listening anxiety and gender the unpaired paradigm t-test was used. According to this, on the "1st Factor" dimension, there is not a significant difference between male students' anxiety level $\left({ }^{\mathrm{X}}=15.84\right.$ medium level) and the female students' anxiety level $\left({ }^{\mathrm{X}}\right.$ $=15.32$ medium level) and according to $\left.\mathrm{t}_{68}\right)=.41 \mathrm{p}>.05$. On the "2nd Factor" dimension, it has been reached to a conclusion that there is not a significant difference between male students' anxiety level ( ${ }^{\mathrm{X}}=12.74$, medium level) and the female students' anxiety level $\left({ }^{\mathrm{X}}=12.73\right.$ medium level $)$ according to $\mathrm{t}\left({ }_{185}\right)=-1.48 \mathrm{p}>.05$.

On the "3rd Factor" dimension, no significant difference has been detected between the male students' anxiety levels $\left({ }^{\mathrm{X}}=54.36\right.$ medium level $)$ and the female students' anxiety level $\left({ }^{\mathrm{X}}=53.81\right.$ medium level) according to $t(185)=.129, p>.05$. When we look at the general features of the scale, between the anxiety level of male students' $\left({ }^{\mathrm{X}}=54.36\right.$ medium level $)$ and the female students' anxiety level $\left({ }^{\mathrm{x}}=53.81\right.$ medium level $)$ it is seen that there is not a significant difference according to $\mathrm{t}_{(58)}=.24 \mathrm{p}>.05$.

When we look at three sub-dimensions and the overall results of the scale, we can reach the conclusion that there is not a significant difference between the male students' anxiety levels and the female students' anxiety levels that learn Turkish as a foreign language.

\subsubsection{Age and Listening Anxiety}

Does the listening anxiety in people who learn Turkish as a foreign language differ according to age?

On this research, One-Way Anova Test was used to see if there is any relation between the students' age groups and listening anxiety. According to this, when we look at every sub- dimension and the general data to compare the listening anxiety of the students who learn Turkish as a foreign language and their age groups, we can see that on " 1 st Factor" dimension, according to $\mathrm{F}(3-183)=.102, \mathrm{p}>.05$ there is not a significant difference between students' ages and listening anxiety. On "2nd Factor" dimension, according to $\mathrm{F}(3-183)=1.096, \mathrm{p}>.05$ there is not a significant difference between students' ages and listening anxiety. On " $3{ }^{\text {rd }}$ Factor" dimension, according to $\mathrm{F}(3-183)=.389, \mathrm{p}>.05$ there is not a significant difference between students' ages and listening anxiety. When we look at the general data of the scale, it can be said that there is not a significant difference between the students' age groups and listening anxiety according to $\mathrm{F}(3-183)=.744, \mathrm{p}>.05$.

\subsubsection{Education Level and Listening Anxiety on Research}

Does the listening anxiety in people who learn Turkish as a foreign language differ according to education level?

On this research, One-Way Anova Test was used to see if there is any relation between the students' education levels and listening anxiety. According to this, when we look at every sub- dimension and the general data to compare the listening anxiety of the students who learn Turkish as a foreign language and their education levels (high school, bachelor, master, doctorate) we can see that on " 1 st Factor" dimension, according to $F\left({ }_{3-183}\right)=.752$, p>.05 there is not a significant difference between students' education levels and listening anxiety. On " $2{ }^{\text {nd }}$ Factor" dimension, according to $\left.\mathrm{F}_{3-183}\right)=.859, \mathrm{p}>.05$ there is not a significant difference between students' education levels and listening anxiety. On " 3 rd Factor" dimension, according to $\mathrm{F}(3-183)=.818, \mathrm{p}>.05$ there is not a significant difference between students' education levels and listening anxiety. When we look at the general data of the scale, it can be said that there is not a significant difference between the students' education levels and listening anxiety according to $\mathrm{F}(3-183)=1.82, \mathrm{p}>.05$.

\subsubsection{Other Known Foreign Languages and Listening Anxiety}

Does the listening anxiety in people who learn Turkish as a foreign language differ according to their situation of knowing one or more other foreign languages?

On this research, One-Way Anova Test was used to see if there is any relation between the number of foreign languages they know and listening anxiety. According to this, the student's anxiety towards the listening skill and the number of foreign languages they know has been examined. When we look at the results, on " 1 st Factor" dimension, according to $\left.\mathrm{F}_{1-184}\right)=.616, \mathrm{p}>.05$ there is not a significant difference between the number of foreign languages they know and the listening anxiety. On " 2 nd $F$ actor" dimension, according to $\mathrm{F}(1-184)=.785, \mathrm{p}>.05$ there is not a significant difference between students' number of foreign languages they know and the listening anxiety. On " 3 rd Factor" dimension, according to $\mathrm{F}\left({ }_{1-184}\right)=.392, \mathrm{p}>.05$ there is not a significant difference between the number of foreign languages they know and the listening anxiety. When we look at the general data of the scale, it can be said that there is not a significant difference between the number of foreign languages the students know and the listening anxiety according to $\mathrm{F}(1-184)=.170, \mathrm{p}>.05$.

\subsection{Opinions of the Students about Listening Anxiety Who Learn English as a Foreign Language}

What are the opinions of the students about listening anxiety who learn Turkish as a foreign language?

In order to find an answer to this sub-problem, 7 questions on the semi-structured interview form was used. The answers of the students were given below without any alterations. 
S.1. How do you feel during the listening activities that are done in the classroom?

Table 5. The Frequency and Percentage Distribution of the Students' Feelings during Listening

\begin{tabular}{|c|c|c|}
\hline Feelings & f & Percent \\
\hline Anxious & 5 & $\% 41.6$ \\
\hline Fear & 3 & $\% 25$ \\
\hline Fussy & 1 & $\% 8.4$ \\
\hline Annoying and bad & 2 & $\% 16.6$ \\
\hline Exciting & 1 & $\% 8.4$ \\
\hline
\end{tabular}

It is understood that the beginner level $(\mathrm{A} 1, \mathrm{~A} 2)$ students who learn Turkish as a foreign language generally feel anxious, exciting and fear during the classroom listening exercises. This situation arises from the student's lack of vocabulary knowledge, the inability to pronounce the words they know correctly and the fact that the person who reads the text is reading it too fast. The more skillful the students get the less negative feelings they have. They can even find themselves completely free of these thoughts.

S.2. How do you feel while listening to a Turkish Speaker in daily life?

Table 6. The Frequency and Percentage Distribution of the Students Feelings While They're Listening to Someone Speaking Turkish in Daily Life

\begin{tabular}{|c|c|c|}
\hline Feelings & f & Percent \\
\hline Fear and anxious & 3 & $\% 33.3$ \\
\hline Fear & 1 & $\% 11.1$ \\
\hline Fussy & 1 & $\% 11.1$ \\
\hline Ashamed and sweaty & 1 & $\% 11.1$ \\
\hline Comfortable & 2 & $\% 22.3$ \\
\hline Angry & 1 & $\% 11.1$ \\
\hline
\end{tabular}

It is understood that the individuals who learn Turkish as a Foreign Language feel anxiety at first as they listen to someone speaking Turkish in daily life. The reason of this anxiety can be the pronunciation differences specific to one area, the relationship level of the speaker and personal traits (embarrassment, shyness etc.) on advanced levels, as the students have better Turkish language skills, it is seen that the factors that cause the anxiety disappears hence, the individuals feel more comfortable.

S.3 What kinds of Difficulties Do You Encounter with During Listening Activities?

Table 7. The Frequency and Percentage Distribution of the Difficulties the Students Encounter With During a Listening Activity

\begin{tabular}{|l|c|c|}
\hline \multicolumn{1}{|c|}{ Difficulties } & f & Percentage \\
\hline \multicolumn{1}{|c|}{ Stuck to words } & 3 & $\% 30$ \\
\hline Unable to understand listened things due to be fast & 3 & $\% 30$ \\
\hline $\begin{array}{l}\text { Unable to understand because of non-academic } \\
\text { speaking }\end{array}$ & 1 & $\% 10$ \\
\hline Unable to understand the structure of grammar & 2 & $\% 20$ \\
\hline $\begin{array}{l}\text { Unable to understand the gestures and mimics of the } \\
\text { spoken person. }\end{array}$ & 1 & $\% 10$ \\
\hline
\end{tabular}

According to student opinions, the difficulties of the individuals who learn Turkish as a second language during a listening activity can be examined under four categories. Being stuck to a word and failing grasp the whole, the state of confusion caused by the lack of grammar knowledge, not being able to see the gestures or mimics of the speaker, the fast pace of the person who reads the texts.

S.4. Can You Concentrate While the Teacher is doing the Listening Activity? (What do you do to focus on the activity when you can't concentrate?)

Table 8. The Frequency and Percentage Distribution of the Student's Concentration Status during a Listening Activity

\begin{tabular}{|c|c|c|}
\hline Concentration Status & $\mathrm{f}$ & Percentage \\
\hline I can get my attention & 5 & $\% 50$ \\
\hline I can't get my attention & 5 & $\% 50$ \\
\hline
\end{tabular}

During the interviews with the students who learn Turkish as a foreign language, it is seen that half of the students are able to concentrate during the listening activities. Based on the student opinions, we can say that the existing lack of concentration is generally because students get stuck on words. When they get distracted students generally ask questions to their peers or teachers.

S.5. How do you feel when you don't exactly understand when your teacher speaks Turkish to you in the classroom?

Table 9. The Frequency and Percentage Distribution of the Emotions the Students Feel When They Don't Understand Their Teacher

\begin{tabular}{|c|c|c|}
\hline Feelings & f & Percent \\
\hline I am ashamed & 3 & $\% 23$ \\
\hline I feel like a lazy & 2 & $\% 15.4$ \\
\hline I'm worried & 4 & $\% 30.8$ \\
\hline $\begin{array}{c}\text { I'm scared and I do not want to be } \\
\text { humiliated. }\end{array}$ & 2 & $\% 15.4$ \\
\hline I'm concerned & 1 & $\% 7.7$ \\
\hline I want to go back to my country. & 1 & $\% 7.7$ \\
\hline
\end{tabular}

Individuals who learn Turkish as a foreign language get anxious when they don't understand what their teacher says in the classroom and they give way to feelings such as embarrassment, fear and idleness. Also some others are too shy to ask the parts that they don't understand, and they think that the teacher will get mad at them. These individuals also have a fear of "being humiliated" in front of the teacher and the other students. In these kinds of situations, the teacher's positive attitude and behaviors helps the students get through the state of over anxiety.

S.6. Do you get anxious during a listening activity when the listening text is too long?

Table 10. The Frequency and Percentage Distribution of the Students' State of Anxiety When the Listening Text is Too Long

\begin{tabular}{|c|c|c|}
\hline Feelings & $\mathrm{f}$ & Percent \\
\hline I'm worried & 6 & $\% 60$ \\
\hline I'm not worried & 4 & $\% 40$ \\
\hline
\end{tabular}


If the listening text is too long or the person who is reading the text has a fast pace during the listening exercises that are conducted in the classroom, it causes the students to fail to understand what they are listening to which puts them in a state of despair. In order to prevent a situation like this, standard Turkish should be used in the listening audio and the speaker should speak clearly without being too fast. When the listening text is too long, the teacher should pause from time to time and help out the students. The listening audio should be played three times.

S.7. Do you do any other exercises to improve your listening skill? (If the answer is yes, what kind of exercises do you do and how often?)

Table 11. Frequency and Percentage Distribution of the Non-Class Activities Students Do

\begin{tabular}{|c|c|c|}
\hline Activity & $\mathrm{f}$ & Percent \\
\hline I'm talking to people & 5 & $\% 22.8$ \\
\hline I'm watching TV & 3 & $\% 13.6$ \\
\hline I listen to music & 6 & $\% 27.3$ \\
\hline I watch movies and TV series & 7 & $\% 31.8$ \\
\hline I listen to the radio & 1 & $\% 4.5$ \\
\hline
\end{tabular}

The individuals who learn Turkish as a foreign language practice out of class to improve their listening skills. For example, watching a movie or TV series at the cinema, on the TV or computer, listening to a song on the radio and trying to understand what a native Turkish speaker says.

\section{Conclusions}

Listening anxiety which is a state of distress that affects the learning process is defined as a type of anxiety that surfaces in situations when an individual with insufficient knowledge of the target language needs to use that language [19]. Thus, it separates from the general types of anxiety as it's connected to the individual's attitude towards a foreign language. As foreign language anxiety is a specific to learning a new language, language classes are environments where high anxiety occurs. In addition to this, individuals who have high motivation on fields like music, math and science lose their motivation during learning a new language and the reason for this is found to be learning a foreign language in a classroom environment [14].

Cheng, Horwitz and Schaller's [31] studies reached to the conclusion that foreign language anxiety is different from other types of anxiety, how it arouses the fear of negative evaluation in students and how that affects their learning process negatively. According to Young, the reason for foreign language anxiety can be the characteristics of the teacher's or the education. The student's personal problems, communication problems, low self-esteem, the fear of losing their identity, competitiveness, unrealistic expectations and beliefs towards learning provides a basis to anxiety. How some teachers use fear to motivate the students to learn, error correction, being tough or condescending during a feedback are factors that elevates anxiety [32].

Under the light of these studies, anxiety, which is specifically about human psychology are defined on six different axes which are psychologic, biophysiological, physical, sensual, cognitive and behavioral, is adapted to the field of language teaching [33]. When we look at the studies which are done according to the anxiety's harmful effects on the process of learning a foreign language, we can see that most of these studies focus on teaching English. When the results of these studies are taken into consideration, it is possible to say that some strategies, methods and techniques are developed. However, it is pretty hard to say that the studies in which the connection between language anxiety and teaching Turkish to foreigners is being examined are enough. Thus, the purpose of this study is to expose the level and reasons of anxiety which occurs during the process of teaching listening skills to individuals who learn Turkish as a foreign language.

High levels of anxiety for people who learn Turkish as a foreign language is a situation which should be eliminated during the period of education. The inconveniences and the deviation of the listening aim that occur while helping students acquire communication skills in Turkish, elevates the level of anxiety in individuals. The inconvenience that occurs because of the negative anxiety that surfaces during listening is going to directly affect the other language skills that are used during communication. Thereby, the way of talking about language skills and learning other skills is goes through listening activities [34]. The researches carried out by Horwitz and friends [14] revealed that anxiety is connected to listening and speaking skills. This situation makes "listening" be the most important skill in both language education and everyday life. Nevertheless, the listening skill is one of the most neglected core language skills. When we look from this angle, it is very important to unveil the level of listening anxiety in people who learn Turkish as a foreign language because the only way to solve this problem is to detect the reasons behind it. For this reason, the levels and sources behind listening anxiety in individuals who learn Turkish as a foreign language are examined using personal information form, Foreign Language Anxiety Scale and semi-structured interview form. The data obtained in this direction are:

- The reasons of the listening anxiety in individuals who learn Turkish as a foreign language are generally collected in three groups : "pronunciation, stress and intonation, rate of speech and body language", "the fear of not being able to understand the whole by missing a part during listening" and "confidence"

- A significant difference was not found when the genders of the participants are compared with anxiety in individuals who learn Turkish as a 
foreign language. Thus, it can be said that gender differences is not a factor that affects anxiety of listening Turkish as a foreign language.

- A significant difference was not found when the levels of education of the participants are compared with the anxiety in individuals who learn Turkish as a foreign language. This situation shows that the anxiety factor in foreign languages is most likely more about the personality traits rather than the level of education.

- A significant difference was not found when the age groups of participants' are compared with the anxiety in individuals who learn Turkish as a foreign language. The result that there is not a significant difference between the participants' age groups and the anxiety that the individuals who learn Turkish as a foreign language go through matches up with Melanlıoğlu, Demir [35] and Boylu, Çangal's [36] studies.

- When we look at how the number of other foreign languages the individuals who learn English as a foreign language knows affects the listening anxiety, a significant difference was not found at any level. On the researches that has been done till now, it is stated that knowing more than one foreign language is actually beneficial while learning a new one. However, when it comes to a psychological matter like anxiety, it can be said that this situation is not valid.

- At the end of the interviews that was done with 10 volunteers who learn Turkish as a foreign language, the students stated that they have gone through high levels of anxiety at the beginning. As the students' Turkish language skills develop, the high levels of anxiety turned into a medium level anxiety. However, no matter what the student's Turkish language level is, teacher based problems, students' personal characteristics, and listening audio based problems causes the students to feel high levels of anxiety.

The teachers should prepare their students for the lesson before the listening exercises when teaching Turkish as a foreign language. Warm-up activities teachers do before they start listening (short and funny videos, pictures etc.) elevates the confidence in their students, resulting in the reduction of the listening anxiety. Moreover, the teachers who are going to teach Turkish as a foreign language should have an adequate level of pronunciation, stress and intonation. The teachers should be able to adjust their rate of speech during communication so that the students can have a clear understanding and they should use their words in a clear and correct way. A teacher who is being understood correctly by his or her students, helps reducing the anxiety the students might experience. In addition to this, we shouldn't forget that the person who teaches a foreign language provides a model to the students.
It is a known fact that a positive classroom environment makes education easier. Sincere and loving environments will eliminate the anxiety that comes from the fear of "humiliation "to a considerable extent. Therefore, the teacher should have a sincere and loving approach to his or her students and help them get to know each other. In addition to this, a teacher should smile often and answer to his or her students' questions with sincerity and frankness. This kind of manner will help preventing the negative thoughts of students about the target language. Moreover, the fact that the institutions that teach Turkish as a foreign language, doesn't take listening as a separate skill is also an important problem. It is clear that the inadequate attention paid to listening lessons has a negative effect on student's development of the listening skill. This drawback was also mentioned during one on one interview with the students. Furthermore, it is mandatory to enrich the materials that are being used in the classroom in order to help students improve the listening skill.

At the end of the research, it is recommended to conduct the studies about anxiety the students go through while teaching Turkish, should be done in detail and separately taking consideration of the other Turkish language skills as well. In the light of these evaluations, it is thought that the productivity of language teaching can be elevated to the desired extend by preparing a program to cope with the foreign language anxiety and memorizing words, getting students to comprehend the grammatical structures, giving seminars on topics such as anxiety control within the framework of this program.

\section{REFERENCES}

[1] Saussure, F. (1998). Genel dilbilim dersleri. (B. Vardar, Çev.) İstanbul: Multlingual.

[2] Önem, E. (2011). Bireysel dil kullanımını etkileyen etkenler. Dil Dergisi, 152, 57- 67. [Online] Available: http://dergiler.ankara.edu.tr/dergiler/27/1772/18754.pdf (June 3, 2015)

[3] Chomsky N. (2002). Syntatic Structures. Berlin: Mouton de Gruyter.

[4] Köknel, Ö. (1995). Kaygıdan mutluluğa kişilik. İstanbul: Altın Kitaplar.

[5] Geçtan, E. (1981). Çağdaş yaşam ve normal dışı davranışlar. Ankara: Maya.

[6] Scovel, T. (1991). The effect of effect on foreign language learning: a review of the anxiety research. A Journal of Research in Language Studies, 28(1), 129-142.

[7] Morgan, Clifford T. (1998). Psikolojiye giriş. Ankara: Hacettepe Üniversitesi Psikoloji Bölümü Yayınları.

[8] Spielberger, C. D., \& Gonzales, H. P., Taylor, C. J., \& Algaze, B., \& Anton, W. D. (1978). Examination stress and test anxiety. New York: Hemisphere/Wiley. 
[9] Bilgin Ş. (2001). Ergenlerde kayg1 ile benlik saygıs1 arasındaki ilişki. Yüksek Lisans Tezi, Marmara Üniversitesi Eğitim Bilimleri Enstitüsü, İstanbul.

[10] Türk Dil Kurumu. (2011). Türkçe sözlük. Ankara: Türk Dil Kurumu.

[11] Özdal, F., \& Varal, N. (2005). Baba yoksunu olan ve anne-babası ile yaşayan çocukların kaygı düzeylerinin incelenmesi. Gazi Üniversitesi Kırşehir Eğitim Fakültesi Dergisi, 6(2), 255-267.

[12] Ergür, D. O. (2004). Yabancı dil öğrenimi sürecinde kayg1. Hacettepe Üniversitesi Eğitim Fakültesi Dergisi, 26, 48-53.

[13] Akgün, A., \& Gönen, S., \& Aydın, M. (2007). İlköğretim Fen ve Matematik Öğretmenliği öğrencilerinin kayg1 düzeylerinin bazı değişkenlere göre incelenmesi. Elektronik Sosyal Bilimler Dergisi, 6(20), 283-299.

[14] Horwitz, E., \& Michale B., \& Cope J. (1986). Foreign Language Classroom Anxiety. The Modern Language Journal, 70(2), 125-132.

[15] Guiora, A. Z. (1983). The dialectic of language acquisition. Language Learning, 33(5), 3-12.

[16] Scovel, T. (1978). The effect of affect. A review of the anxiety literature. Language Learning, 28, 129-142.

[17] MacIntyre, P.D., \& Gardner, R.C. (1991). Language anxiety: Its relation to other anxieties and processing in native and second languages. Language Learning, 41(4), 513-54.

[18] Littlewood W (1984). Foreign and Second Language Learning: Language Acquisition Research and its Implications for the Classroom. Cambridge: CUP.

[19] MacIntyre P.D., Gardner R.C. (1994). The subtle effects of language anxiety on cognitive processing in the second language. Language Learn. 44(2):283-305.

[20] Young, D. J. (1991). Creating a low-anxiety classroom environment: What does the language anxiety research suggest? Modern Language Journal, 75, 425-439.

[21] Taylor, S. E. (1964). Listening: what research says to the teacher? National Education Association of U.S., 29, 3-32.

[22] Conaway, M. S. (1982). Listening: Learning too and retention agent, in improving reading and study skills. San Francisco: Jossey-Bass.

[23] Özbay, M. (2009). Anlama Teknikleri II: Dinleme Eğitimi. Ankara, Öncü Kitap.

[24] Çiftçi, M. (2001). Dinleme eğitimi ve dinlemeyi etkileyen faktörler. Afyon Kocatepe Üniversitesi Sosyal Bilimler Dergisi, 2 (2).

[25] Yalçın, A. (2002). Türkçe öğretim yöntemleri yeni yaklaşımlar. Ankara: Akçağ.

[26] Özdemir, E. (2013). Türkçeyi yabancı dil olarak öğrenenlerin konuşma kaygılarının kaynakları. Yüksek Lisans Tezi, Gazi Üniversitesi Eğitim Bilimleri Enstitüsü, Ankara.

[27] Doğan, Y. (2011). Dinleme eğitimi. Ankara: Pegem Akademi.

[28] Kalaycı, N., Temur, T. (2005). İlköğretim okullarında dinleme becerisini nasıl geliştirebiliriz? Eğitime Bakış: Eğitim- Öğretim ve Bilim Araştırma Dergisi, (1)2, 53-63.

[29] Büyüköztürk, Ş. (2011). Sosyal bilimler için veri analizi el kitab1. Ankara: Pegem Akademi.

[30] Karasar, N. (2009). Bilimsel araştırma yöntemi. Ankara: Nobel.

[31] Cheng, Y., Horwitz, E.K., Schallert, D.L. (1999). Language writing anxiety: Differentiating writing and speaking components. Language Learning, 49, 417-446.

[32] Batumlu, D.Z., \& Erden, M. (2007). Yıldız Teknik Üniversitesi Yabanc1 Diller Yüksekokulu hazırlık öğrencilerinin yabancı dil kaygıları ile İngilizce başarıları arasındaki ilişki. Eğitimde Kuram ve Uygulama, 3(1), 24-38.

[33] Beck, A. T., Emery, G., Greenberg, R. L. (1985). Anxiety disorders and phobias: A cognitive perspective. New York, NY: Basic Books.

[34] Mackay, I. (1997). Dinleme becerisi (A. Bora ve O. Cançolak, Çev.). Ankara: İlkkaynak.

[35] Melanlıoğlu, D., \& Demir, T. (2013). Türkçe öğrenen yabancılar için konuşma kaygısı ölçeğinin Türkçe formunun geçerlik ve güvenirlik çalışması. The Journal of Academic Social Science Studies, 6(3), 389-404.

[36] Boylu, E., \& Çangal, Ö. (2015). Yabancı dil olarak Türkçe öğrenen Bosna - Hersekli öğrencilerin konuşma kaygılarının çeşitli değişkenler açısından incelenmesi. Turkish Studies. 4(1), 349-368.

[37] Kim, J. (2000). Foreign language listening anxiety: A study of Korean students learning English. Doctoral Dissertation, the University of Texas at Austin, Texas.

[38] Kılıç, M. (2007).Yabancı dilde dinleme kaygısının metin türü ve ögrenen değişkenleri ile bağlantıl olarak kaynak ve ilişkileri: Gaziantep Üniversitesi'nde bir örnek-olay incelemesi. Yüksek Lisans Tezi, Gaziantep Üniversitesi Sosyal Bilimler Enstitüsü, Gaziantep.

[39] Akalın, Ş. H. (2004). Türk Dili Dünya Dili. [Online] Available:

http://www.tdk.gov.tr/images/stories/eskidosyalar/turkdilid unyadili.pdf(May 26, 2015)

\footnotetext{
${ }^{\mathrm{i}}$ This research is part of the master thesis prepared by Sercan Halat under the supervision of Prof. Dr. Murat Özbay.
} 